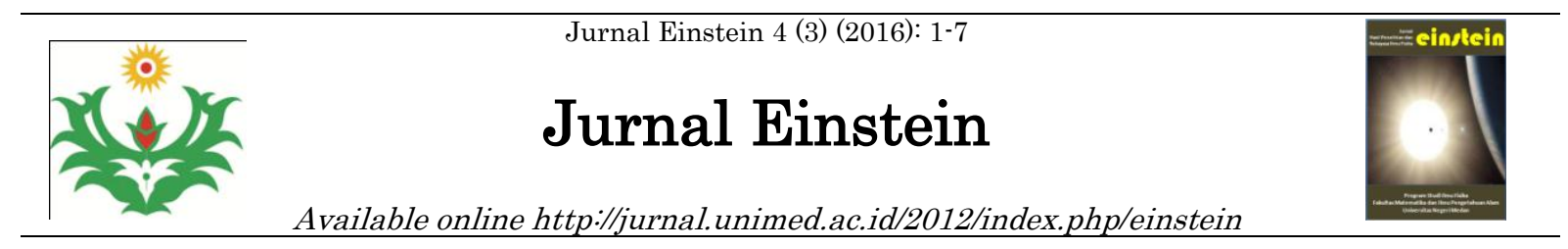

\title{
Rancang Bangun Penghitung Obat Secara Otomatis Dengan Menggunakan Mikrokontroler At89s51 Memanfaatkan Inframerah Dan Photodioda
}

\author{
Kadri Ginting dan Abd Hakim S*
}

Jurusan Fisika, Fakultas Matematika dan Ilmu Pengetahuan Alam, Universitas
Negeri Medan, Indonesia

Diterima Agustus 2016; Disetujui September 2016; Dipublikasikan Nopember 2016

\begin{abstract}
Abstrak
Tujuan dari penelitian ini adalah untuk membuat hardware dan sofware yang digunakan sebagai alat pencacah obat, untuk membuat rangkaian mekanik secara otomatis. Penelitian ini menggunakan fotodioda sebagai sensor penerima yang memberikan hasil cacahan dan inframerah sebagai pemancar cahaya. Metode yang digunakan melakukan pengujian sensor terhadap diameter obat yang berbeda, melakukan pengujian sensitivitas sensor, pengujian ketepatan pencacahan, waktu pencacahan obat dan pengujian kualitas alat yang dirancang. Hasil penelitian ini menunjukkan bahwa: Sensor dapat berfungsi dengan baik dan dapat mencacah obat tablet dengan diameter $<1 \mathrm{~cm}$. Hal ini dibuktikan dengan ketepatan sensor mencacah obat tablet dengan diameter $0,75 \mathrm{~cm}$. Pada pengujian sensitifitas sensor, obat dapat dicacah dengan baik apabila jarak antara suatu obat dengan obat lainnya apabila jaraknya $\geq 1 \mathrm{~cm}$. Pencacahan obat bekerja dengan baik yang dibuktikan dengan jumlah obat yang ditampilkan pada LCD sama dengan jumlah obat yang dihitung secara manual. (4) Alat hanya dapat mencacah secara terus menerus dengan tepat selama 8 menit dan dapat mencacah dengan tepat lagi apabila kondisi alat sudah normal kembali.
\end{abstract}

Kata kunci: Mikrokontroler AT89S51, fotodioda, inframerah, motor DC, sistem otomatis, tampilan LCD

How to Cite: Kadri Ginting dan Abd Hakim S, (2016), Rancang Bangun Penghitung Obat Secara Otomatis Dengan Menggunakan Mikrokontroler At89s51 Memanfaatkan Inframerah Dan Photodioda, Jurnal Einsten Prodi Fisika FMIPA Unimed, 4 (3) : 1-7.

${ }^{*}$ Corresponding author:
E-mail : kadriginting@yahoo.com

p-ISSN : $2338-1981$

e-ISSN : $2407-747 x$ 


\section{PENDAHULUAN}

Dalam dunia industri tekonologi dimanfaatkan sebagai pengendali yang berguna untuk meningkatkan kelancaran dalam suatu pekerjaan. Banyak sistem manual dibuat menjadi otomatis karena penggunaanya lebih praktis dan pekerjaan yang dilakukan menjadi lebih efektif. Sehingga dengan perkembangan teknologi sistem kendali di dunia industri, sistem pengendalian dan monitoring mulai diambil alih oleh alat kendali untuk menggantikan pekerjaan manual. Pada proses industri manual biasanya dikerjakan oleh tenaga manusia tetapi sering terjadi human error hal ini disebabkan karena melakukan pekerjaan secara berulangulang. Untuk mengatasi masalah tersebut, suatu industri yang menginginkan proses produksi yang lebih efektif dan efisien melakukan perubahan pola produksi dengan mengaplikasikan sistem otomasi dalam produksinya.

Salah satu teknologi yang diperlukan adalah bagaimana menghitung jumlah barang yang sudah diproduksi untuk pemasarannya. Menurut Wardhana, (2006) untuk membuat suatu rancangan maka diperlukan suatu sistem pengendali. Salah satu alat yang dibutuhkan sebagai sistem pengendali yang bagus dalam suatu rancangan adalah harus menggunakan mikrokontroler. Industri harus selalu memproduksi suatu barang dengan cepat hal ini disebabkan oleh permintaan konsumen setiap tahunnya semakin meningkat. Setiap hari dalam suatu industri akan memproduksi barang produksi secara terus-menerus mesin-mesin dapat bekerja dengan cepat. Semua barang-barang hasil produksi yang akan dihitung sebelum didistribusikan dan barang hasil produksi yang akan dipasarkan harus dalam keadaan baik untuk memuaskan konsumen. Untuk itulah diperlukan suatu alat yang dapat berfungsi secara otomatis untuk menghitung suatu hasil produk.

Berdasarkan penelitian sebelumnya, Siahaan, (2007) membuat suatu rangkaian counter digital sebagai penghitung jumlah produk akhir berbasis mikrokontroler. Alat ini dapat berfungsi sebagai alat penghitung jumlah barang tetapi untuk barang yang berdiameter besar. Hadi dan Nurhayati, (2009) dalam membuat rangkaian penghitung jumlah barang menggunakan laser tetapi alat ini digunakan untuk mendeteksi dua warna saja yaitu warna hitam dan warna putih. Selain itu alat ini tidak dapat bekerja secara terus-menerus. Penelitian ini juga telah dilakukan Yohannes, (2011) dalam pembuatan rangkaiannya menggunakan mikrokontroler ATMEGA 16. Rangkaian ini digunakan untuk menghitung jumlah barang yang mengalami kerusakan dengan menggunakan sensor ultrasonik sebagai pendeteksi. Selain itu, karena alat ini menggunakan ATMEGA 16 sehingga dapat diprogram sekaligus untuk menentukan suatu barang rusak atau tidak.

Berdasarkan uraian diatas, maka dibuat suatu penelitian tentang simulasi alat penghitung barang memanfaatkan inframerah dengan judul "Rancang Bangun Penghitung Obat Secara Otomatis Dengan Menggunakan Mikrokontroler AT89S51 Memanfaatkan Inframerah dan Photodioda". Manfaat dari penelitian ini supaya dapat digunakan industri yang masih menggunakan perhitungan barang secara manual menjadi otomatis. Sehingga dengan rancangan ini maka proses produksi dan pemasaran dapat berjalan dengan baik.

\section{METODE PENELITIAN}

\section{Tempat dan Waktu Penelitian}

\section{Alat dan Bahan}

\begin{tabular}{|l|lr|}
\hline Laboratorium Fisika & Penghisap & timah, \\
FMIPA UNIMED & Solder, & Resistor, \\
& Jangka & sorong, \\
& Multimeter & digital, \\
& Multimeter & analog, \\
\hline
\end{tabular}




\begin{tabular}{|l|l|}
\hline & Gunting, Kabel, \\
& Potensiometer. \\
\hline Toko Elektronika & Saklar, Downloader, \\
& Bor PCB, PCB, Catu \\
& daya 12 volt, LCD \\
& 2x16, inframerah, \\
& potodioda, motor \\
& DCdan Mikrokontroler \\
& AT89S51. \\
\hline
\end{tabular}

\section{Prosedur Penelitian}

1. Menyiapkan alat dan bahan yang diperlukan dan disiapkan dengan kondisi telah diuji.

2. Rangkaian diterjemahkan ke dalam bentuk layout yang telah dibuat dengan menggunakan aplikasi pada komputer untuk dipindahkan ke dalam papan PCB.

3. Melakukan proses pelarutan dengan menggunakan larutan Ferry Chloride $\left(\mathrm{FeCl}_{3}\right)$, sehingga bagian tembaga yang tidak digunakan terbuang dari PCB.

4. Papan PCB yang telah dilarutkan dibersihkan dari tinta pelapis dan dari noda-noda bekas larutan dengan menggunakan kertas pembersih tinta dan juga bekas larutan.

5. Untuk pemasangan komponen terlebih dahulu dilakukan pengeboran untuk melobangi bagian PCB pada layout yang telah ditentukan dan pengecekan lintasan komponen apakah tersambung atau tidak.

6. Penyolderan komponen pada PCB dengan panas yang secukupnya sehingga komponen dapat terikat dengan rangkaian yang telah dibuat.

7. Komponen yang telah dipasang dibersihkan beserta semua permukaan PCB dengan menggunakan tinner. Hai ini bertujuan untuk menghindari efek resistansi dan kapasitansi liar yang tidak diinginkan.

8. Membuat list program assembly kemudian mengdownloader kedalam mikrokontroler AT89S51 dengan menggunakan kit downloader dan software downloader.

9. Melakukan pengujian pada konveyor apakah dapat berfungsi dengan baik atau tidak. Apabila belum sesuai dengan yang diharapkan maka dilakukan pengecekan ulang dan mengatur kecepatan konveyor obat yang disesuaikan dengan kecepatan konveyor botol.

10. Melakukan pengujian pada alat yang dibuat apakah sudah dapatberfungsi untuk mendeteksi dengan baik suatu benda atau tidak dan melakukan pengujian keseluruhan kerja alat.

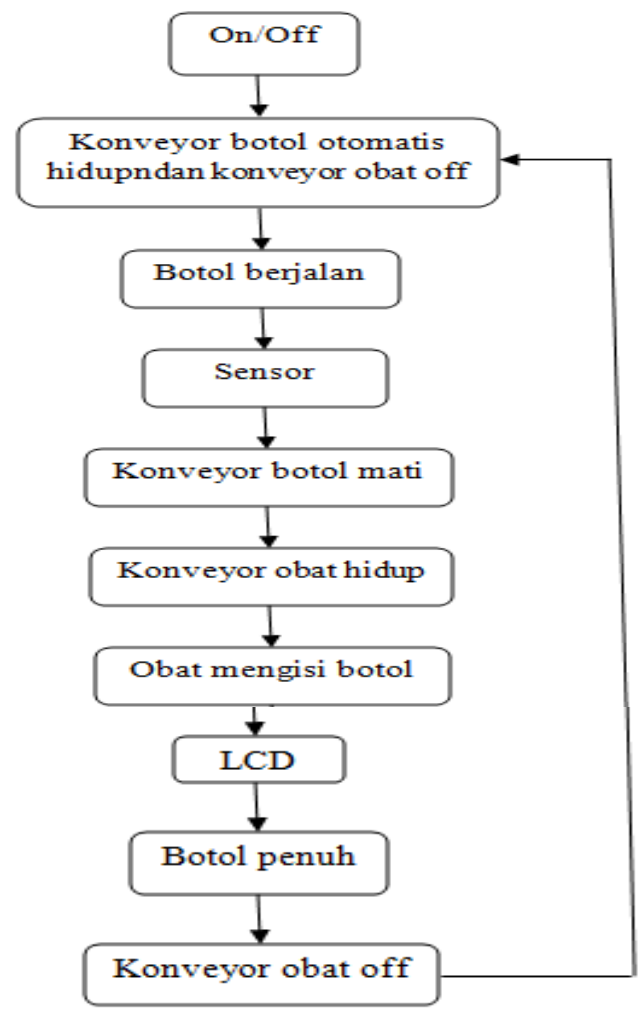

Gambar 1. Diagram alir rancangan

\section{Analisis Data}

Langkah-langkah dalam menganalisa data, yaitu:

1. Pengujian ketepatan perhitungan sensor dengan cara menvariasikan jarak ptodioda dan inframerah. 
Kadri Ginting dan Abd Hakim S, Rancang Bangun Penghitung Obat Secara Otomatis Dengan Menggunakan Mikrokontroler At89s51 Memanfaatkan Inframerah Dan Photodioda

2. Pengujian ketepatan perhitungan sensor terhadap obat kapsul dengan cara membuat variasi diameter obat tablet.

3. Pengujian ketepatan perhitungan sensor terhadap obat kapsul dengan cara membuat variasi diameter obat kapsul.

4. Melakukan pengujian kualitas sensor dengan memvariasikan jarak tiap obat yang melewati sensor.

5. Pengujian alat secara keseluruhan dengan melihat tampilan pada LCD.

6. Melakukan pengujian kualitas alat secara keseluruhan.

\section{HASIL DAN PEMBAHASAN Hasil Penelitian}

Setelah melakukan perakitan dan perancangan maka dilakukan pengujian ketepatan alat dalam mendeteksi dan menghitung jumlah obat yang melewati sensor. Proses cara kerja alat diawali dengan menghubungkan power supply dengan listrik dan menekan tombol ON pada rangkaian. Kemudian layar pada LCD akan hidup sehingga proses perhitungan obat dapat dimulai. Kemudian konveyor pada botol akan bergerak secara otomatis sampai botol terdeteksi oleh sensor. Pada saat terdeteksi secara otomatis konveyor penggerak botol akan berhenti dan secara otomatis konveyor obat akan hidup dan proses perhitungan obat dapat dimulai sampai obat terdeksi. Bila sensor mendeteksi adanya benda maka hasil perhitungan akan tampil pada layar LCD sampai dengan batas maksimum yang dirancang. Setelah jumlah obat pada tampilan LCD menunjukkan jumlah maksimum maka secara otomastis konveyor penggerak obat akan berhenti dan secara otomatis konveyor pada obat akan hidup.

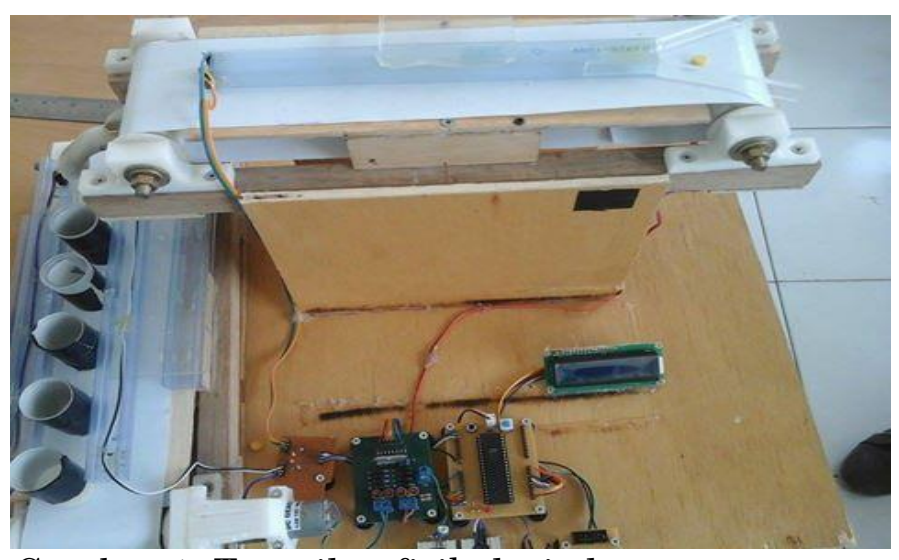

Gambar 1. Tampilan fisik dari alat yang telah dirancang

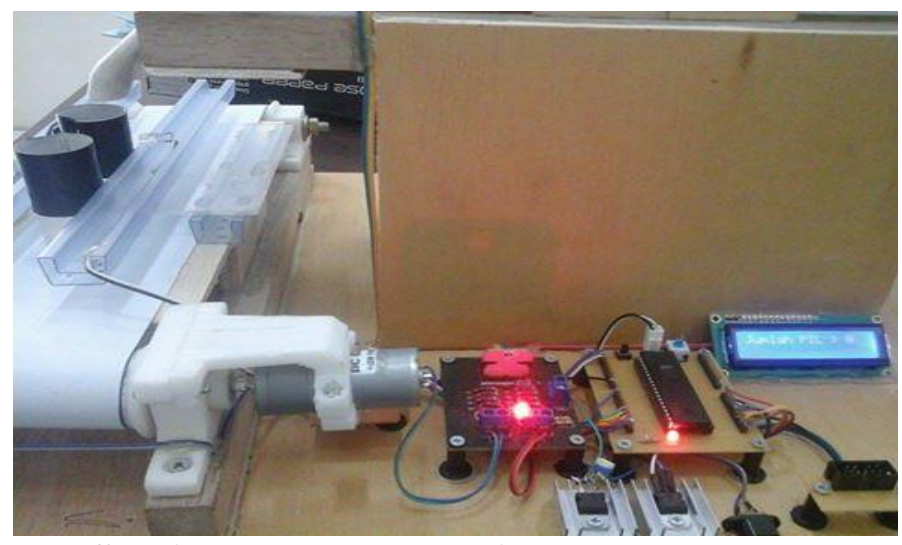

Gambar 2. Pengujian alat secara keseluruhan

Tabel 1. Hasil Pengujian Jarak Sensor Potodioda-Inframerah

\begin{tabular}{|c|c|c|}
\hline No. & $\begin{array}{c}\text { Jarak } \\
\text { photodioda-infra } \\
\text { merah (cm) }\end{array}$ & $\begin{array}{c}\text { Ketepatan } \\
\text { Perhitungan } \\
\text { (LCD) }\end{array}$ \\
\hline 1 & 1 & Tepat \\
\hline 2 & 2 & Tidak tepat \\
\hline 3 & 3 & Tidak tepat \\
\hline
\end{tabular}

penelitian diatas diperoleh suatu jarak antara sensor potodioda dan inframerah yaitu sebesar $1 \mathrm{~cm}$. Dengan jarak tersebut maka ketepatan alat untuk menghitung obat dapat berfungsi dengan baik. 
Tabel 2. Hasil Pengujian Sensor Untuk Obat Tablet

\begin{tabular}{|c|c|c|}
\hline No. & $\begin{array}{c}\text { Diameter obat } \\
\text { (Tablet) }\end{array}$ & $\begin{array}{c}\text { Ketepatan } \\
\text { pembacaan } \\
\text { sensor }\end{array}$ \\
\hline 1 & $0.75 \mathrm{~cm}$ & Tepat \\
\hline 2 & $0.80 \mathrm{~cm}$ & Tepat \\
\hline 3 & $0.95 \mathrm{~cm}$ & Tepat \\
\hline 4 & $1.30 \mathrm{~cm}$ & Tidak Tepat \\
\hline 5 & $1.31 \mathrm{~cm}$ & Tidak Tepat \\
\hline
\end{tabular}

Tabel 3. Hasil Pengujian Sensor Terhadap Obat Kapsul

\begin{tabular}{|c|c|c|}
\hline No. & $\begin{array}{c}\text { Diameter obat } \\
\text { (Kapsul) }\end{array}$ & $\begin{array}{c}\text { Ketepatan } \\
\text { pembacaan }\end{array}$ \\
\hline 1 & $0.59 \mathrm{~cm}$ & tepat \\
\hline 2 & $0.60 \mathrm{~cm}$ & tepat \\
\hline 3 & $0.70 \mathrm{~cm}$ & tepat \\
\hline 4 & $0.71 \mathrm{~cm}$ & tepat \\
\hline 5 & $0.73 \mathrm{~cm}$ & tepat \\
\hline
\end{tabular}

Berdasarkan data hasil penelitian diatas maka dapat dilihat bahwa alat mampu melakukan perhitungan dengan baikdan tepat untuk obat tablet maupun obat kapsul dan ketepatan kurang dari $1 \mathrm{~cm}$ yaitu antara $0.59-0,73 \mathrm{~cm}$.

Tabel 4. Hasil Penelitian Kualitas Sensor Terhadap Jarak Obat

\begin{tabular}{|c|c|c|}
\hline No. & $\begin{array}{c}\text { Jarak tiap obat } \\
\text { (cm) }\end{array}$ & $\begin{array}{c}\text { Pembacaan sensor } \\
\text { (LCD) }\end{array}$ \\
\hline 1 & 0 & Tidak tepat \\
\hline 2 & 0.2 & Tidak tepat \\
\hline 3 & 0.4 & Tidak tepat \\
\hline 4 & 0.6 & Tidak tepat \\
\hline 5 & 0.8 & Tidak tepat \\
\hline 6 & 1 & Tepat \\
\hline
\end{tabular}

Berdasarkan data penelitian diatas dilakukan penelitian untuk mengetahui kualitas sensor yang digunakan dengan membuat jarak antara dua obat. Jarak antara dua obat dimulai pada saat kedua obat berimpit sampai obat dapat mendeteksi kedua obat. Berdasarkan penelitian diketahui bahwa sensor dapat mendeteksi dengan baik apabila jarak kedua obat sebesar 1 $\mathrm{cm}$.

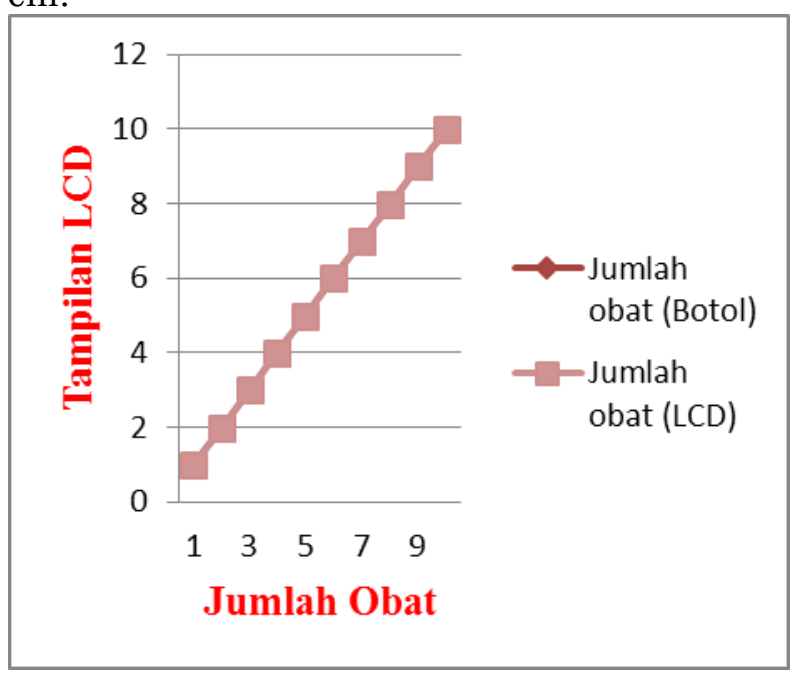

Gambar 3 Grafik Hasil Perhitungan Obat Pada LCD

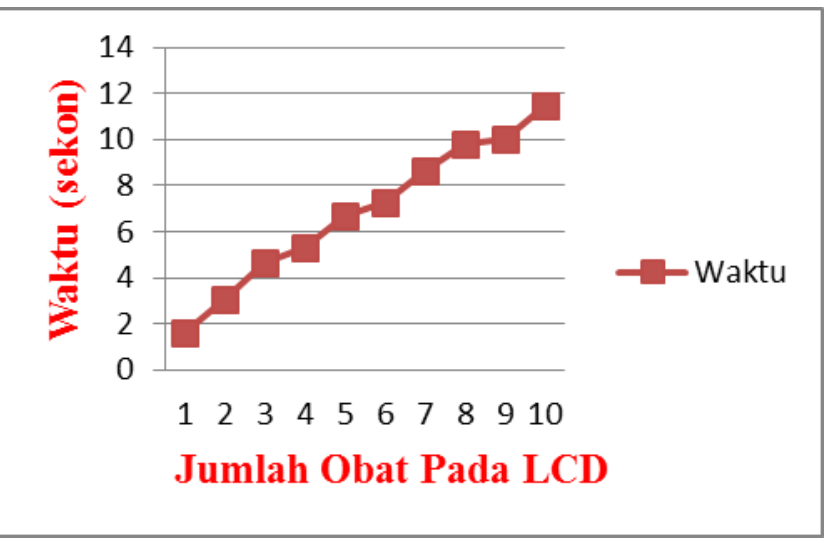

Gambar 4. Grafik Hasil Pengisian Obat

Tabel 5. Hasil Pengujian Kualitas Alat Pada Saat Penggunaan

\begin{tabular}{|c|c|c|c|}
\hline No. & $\begin{array}{c}\text { Waktu } \\
\text { pengecekan }\end{array}$ & $\begin{array}{c}\text { Kondisi } \\
\text { alat }\end{array}$ & $\begin{array}{c}\text { Ketepatan } \\
\text { Perhitungan }\end{array}$ \\
\hline 1 & menit ke-1 & bagus & Tepat \\
\hline 2 & menit ke-2 & bagus & Tepat \\
\hline 3 & menit ke-4 & bagus & Tepat \\
\hline 4 & menit ke-6 & $\begin{array}{c}\text { Sedikit } \\
\text { panas }\end{array}$ & Tepat \\
\hline 5 & menit ke-8 & panas & Tepat \\
\hline
\end{tabular}


Kadri Ginting dan Abd Hakim S, Rancang Bangun Penghitung Obat Secara Otomatis Dengan Menggunakan Mikrokontroler At89s51 Memanfaatkan Inframerah Dan Photodioda

\begin{tabular}{l|l|l|r}
6 & menit ke-9 & $\begin{array}{c}\text { Lebih } \\
\text { panas }\end{array}$ & Tidak tepat \\
\hline \multicolumn{2}{c}{ Dapat diketahui } & bahwa
\end{tabular} kondisialat dari menit pertama sampai menit ke-4 dalam kondisi bagus dan ketepatan perhitungan sensor masih dapat ditampilkan pada LCD sedangkanpada menit ke-6 dan ke-8 kondisi alat sudah mulai panas tetapi ketepatan perhitungan sensor masih berjalan dengan baik dan mulai pada menit ke-9 dengan kondisi alat yang semakin panas maka sensor tidak dapat lagi mendeteksi obat yang mengakibatkan ketepatan dalam perhitungan menjadi tidak tepat.

\section{Pembahasan}

Alat rancangan penghitung obat otomatis menggunakan mikrokontroler AT89S51 dengan memanfaatkan fotodioda dan inframerah. Berdasarkan tabel 3.1.6 menit ke-6 sedikit panas, menit ke-8 panas, dan menit ke-9 lebih panas karena pengaturan tegangan yang belum tepat pada input IC dan input mikrokontroler AT89S51. Hal ini sesuai dengan penelitian sebelumnya Prianto $d k k$, (2011) yang mendapatkan hasil bahwa alat dapat bekerja secara terus-menerus. Perbandingan dengan penelitian sebelumnya pada rancangan terdahulu menggunakan sistem pengendali otomatis dan motor DC dengan volt yang besar sehingga kecepatan konveyor bisa cepat. Sedangkan pada penelitian Rahayuningtyas, (2009) dalam penelitiannya menggunakan 4 buah motor penggerak sekaligus dalam suatu rancangan tetapi dalam penelitian ini kualitas alat yang dirancang hanya bisa bertahan selama 5 menit setelah itu sensor tidak dapat mendeteksi adanya obat yang lewat. Kekurangan penelitian ini disebabkan karena pemakaian motor DC yang berlebihan sehingga pengaturan tegangan tidak dapat berjalan dengan baik.

Berdasarkan tabel 3.1.1. jarak fotodioda dengan inframerah diketahui bahwa fotodioda dapat menerima sinar dari inframerah dengan tepat apabila jarak yang dibuat $1 \mathrm{~cm}$. Diuji dengan obat tablet yang dapat dibaca dengan oleh sensor dengan tepat apabila mempunyai diameter 0.75-0.95 cm sedangkan obat kapsul dapat dibaca dengan tepat apabila diameter kapsul 0.59-0.73cm. Berdasarkan hasil tersebut diketahui bahwa sensor dapat berfungsi dengan tepat apabila diameter obat yang melalui $\leq 1 \mathrm{~cm}$. Keunggulan dari penelitian sebelumnya adalah penelitian ini tentang perancangan perhitungan yaitu dapat meghitung untuk jumlah suatu barang untuk ukuran yang kecil atau berdiameter kecil dapat sekaligus mengisi obat kedalam botol obat. Dalam penelitian ini perbandingan jenis sensor yang digunakan jenis sensor yang mempunyai tingkat efektifitas cahaya kecil dan perancangan mekanikny dibuat khusus supaya sensor dapat mendeteksi ukuran obat yang berdiameter kecil.

Berdasarkan gambar 3.1. menunjukkan ketepatan jumlah obat dengan pembacaan LCD. Sedangkan gambar 3.2. jumlah obat dengan waktu tidak linier karena peletakan obat masih manual seharusnya secara otomatis supaya linier.

\section{KESIMPULAN DAN SARAN \\ Kesimpulan}

Dari hasil penulisan tugas akhir ini tentang rancang bangun alat penghitung jumlah obat secara otomatis menggunakan Mikrokontroler AT89S51 sebagai pengendali dan hasil penelitian yang telah dilakukan, maka penulis dapat mengambil kesimpulan sebagai berikut:

1. Dari rangkaian system rancangan yang telah dibuat, dapat disimpulkan bahwa system alat rancangan seperti rangkaian sensor, rangkaian penampil, rangkaian minimum mikrokontroler dan rangkaian otomatis motor DC yang telah dibuat dapat berfungsi dan 
berjalan dengan baik sehingga dapat difungsikan untuk menghitung obat kedalam botol.

2. Dari program yang telah dimasukkan kedalam mikrokontroler, rancangan dapat melakukan perhitungan dengan baik dan sesuai dengan yang ditampilkan pada tampilan LCD (Light Cristal Display) dan mikrokontroler dapat berfungsi sebagai pengendali sesuai dengan program yang dibuat.

3. Berdasarkan hasil penelitian yang telah dilakukan, dapat disimpulkan bahwa alat dapat melakukan perhitungan jumlah obat dengan baik yang sesuai dengan jumlah obat yang ditampilkan pada LCD dan alat secara keseluruhan dapat berfungsi secara otomatis.

\section{Saran}

Setelah melakukan penulisan tugas akhir ini tentang rancang bangun alat penghitung jumlah obat secara otomatis menggunakan Mikrokontroler AT89S51 sebagai pengendali, maka penulis dapat memberikan saran agar alat ini dapat lebih dikembangkan lagi menjadi lebih baik, yaitu:

1. Untuk menambah berbagai macam jenis obat yang dapat dideteksi maka perlu mengganti sensor inframerah dengan yang lebih canggih lagi yang mempunyai sensitivitas sensor lebih baik seperti menggunakan laser sehingga jarak antara fotodioda dan inframerah dapat diperbesar lagi sehingga obat dengan diameter yang besar dapat terdeteksi.

2. Untuk membuat waktu pengisian obat kedalam botol tetap sama maka perlu dibuat system otomatis pada peletak obatnya sehingga jatuhnya obat bisa dibuat dengan selang waktu yang sama.

3. Untuk menambah kualitas dari pada alat maka perlu dibuat system pendingin pada rangkaian seperti kipas sehingga suhu pada komponen rangkaian dapat terjaga dan membuat alat dapat difungsikan untuk waktu yang lama.

\section{DAFTAR PUSTAKA}

Hadi, I., dan Nurhayati., (2009), Rancang Bangun Alat Pemilah Dan Penghitung Barang Dengan Menggunakan Laser Berbasis Mikrokontroler, Jurusan Teknik Elektro, UNESA.

Prianto, E., Ismara, K.I., dan Asmara, A., (2011), Desain Sistem Kendali Kecepatandan Counter Putaran Berbasis Teknologi Otomasi Pada Industri Kecil dan Menengah: 1412-9612.

Rahayuningtyas, A., (2009), Pembuatan Sistem Pengendali 4 Motor DC Penggerak 4 Roda Secara Independent Berbasis Mikrokontroler AT89C2051: 0854-3046.

Siahaan, J.C., (2007), Perancangan Counter Digital Sebagai Penghitung Produk Akhir Berbasis Mikrokontroler, Tugas Akhir, Fisika FMIPA, USU, Medan.

Wardhana, L., (2006), Belajar Sendiri Mikrokontroler AVR Jeri ATMEGA 32 Simulasi Hardware Aplikasi, Andi Offset, Yogyakarta.

Yohannes, C., (2011), Sistem Penghitung Jumlah Barang Otomatis Dengan Sensor Ultrasonik, Jurnal Ilmiah Elektrikal Enjiniring, UNHAS. 